[Jpn. J. Agric. Econ. Vol.23, pp.137-142, 2021]

\title{
The Impact of Quarantine against Foot-and-Mouth Disease in Mongolia on Pastoralists' Farming Performance and Welfare
}

\author{
Davaatseren Narmandakh $^{1}$ and Takeshi Sakurai ${ }^{1 *}$
}

Infectious animal diseases have become prevalent occasionally in developing countries due to their weak animal health system and hinder their potential of livestock and livestock product exports. Mongolia since the early $2000 \mathrm{~s}$ has experienced frequent outbreaks of foot-and-mouth disease (FMD) that result in prolonged quarantine in affected areas. Difference-in-Differences estimates suggest that herders in the quarantine zones had smaller herds, especially smaller cattle herd after the quarantine. We also observe a significant decrease in byproduct sales revenue and feed cost. We find, however, null evidence that FMD quarantine negatively impacted household's farm income, farm profit, or total income.

Key words: pastoralism, livestock diseases, quarantine

\section{Introduction}

Globalization is driving structural change in livestock sector, which supports the livelihoods of poor people in the world. For instance, strengthened regulations of food safety and animal health are creating market barriers for developing countries with weak animal health systems and as a result affect people's livelihood (Rae and Nayga, 2013). Once a notifiable disease ${ }^{1)}$ is discovered in a country, the country's livestock sector experiences severe shocks, including those resulting from direct losses of livestock, decrease in production, productivity and profitability caused by the disease, and the cost of the treatment as well as control measures such as culling, quarantines, and travel bans that disrupt local markets and international trade (FAO, 2009).

Mongolia is one of such developing countries that have a significant livestock sector ${ }^{2)}$. Mongolian livestock sector is dominated by pastoralist small-scale farmers, who rear 99.5\% of livestock in transhumance (National Statistics Office of Mongolia, 2019) and move with their livestock to distant grazing areas usually on a seasonal cycle ${ }^{3)}$. Due to their dependence on rangelands, pastoralist herders in Mongolia just like those in other developing countries are often constrained by major shocks related to extreme weather

${ }^{1}$ The University of Tokyo

Corresponding author*: takeshi-sakurai@g.ecc.u-tokyo.ac.jp

1) List of diseases established by the World Organization for Animal Health (OIE) in line with Sanitary and Phytosanitary Agreement of the World Trade Organization (WTO).

2) The livestock sector of Mongolia contributes up to $10.8 \%$ of the total GDP and $9.2 \%$ of the country`s export and employs $26.7 \%$ of the total labor force. events, civil conflict, fluctuating prices, and outbreaks of animal diseases (Cervigni and Morris, 2016). For many years now, programs and policies designed to increase the production and export of meat and meat products have been featured highly on the political agenda (Parliament of Mongolia, 2015). However, a major hindrance in exporting livestock and livestock products is the increasing outbreaks of livestock infectious diseases.

One of such infectious diseases is foot-and-mouth disease (hereafter referred as FMD). While Mongolia had had no cases of FMD from 1974 until June 2000, during the last 20 years the occurrence of FMD outbreaks has increased (Figure 1). Since the early 2000s, FMD outbreaks in Mongolia have caused countries such as China, Russia, and Iran to impose export bans of meat and meat products on some Mongolian provinces $^{4}$ (Purevkhuu, 2016). During the period 2000-2016, a total of 62.8 billion Mongolian tugrugs (about 31 million USD) was spent on indemnity payments, preventative measures as well as control activities after outbreaks (Parliament of Mongolia, 2020). Existing animal disease literature mainly focuses on epidemiological models to study the transmission of infection and recently incorporates human behavior (the social planner) to identify the most

3) Recent data show that some pastoralists in Mongolia move more than 4 times a year. Moreover, sometimes all household members move permanently while in other cases only males leave for grazing for a few months in a year.

4 ) Current sanitary and phytosanitary agreements between Mongolia and other countries mostly state that no animal products shall be exported from a province with an FMD outbreak in the last 12 months. 


$$
\begin{array}{cccccccccccccccc}
17 & & 18 \\
2 & 0 & 0 & 1 & 0 & 0 & 0 & 0 & & 0 & 0 & 3 & 1 & 1 \\
\hline \\
\hline
\end{array}
$$

Figure 1. Frequency of FMD outbreaks in Mongolia Source: OIE's World Animal Health Information System (WAHIS) and Mongolian National Archives.

efficient way to decrease the marginal cost of eradication. These studies are mostly done by simulation and/or based on case studies in developed countries (Rich and Winter-Nelson, 2007; Wang and Hennessy, 2015). On the other hand, the impact of FMD outbreak on smallholder farmers is rarely studied due to lacking data, and the few existing ones focus only on the direct impact of an outbreak where households are submitted to compulsory culling of their livestock (Knight-Jones et al., 2017). Indirect impact of FMD outbreak such as how control measures affect the pastoralists' livelihoods is still unknown.

The objective of this paper is to help fill in this gap in the literature by studying the impact of living near the FMD outbreak and experiencing prolonged quarantine.

The remainder of the paper is organized as follows. Section 2 describes the 2014 FMD outbreak and its aftermath quarantine and documents our data sources. Section 3 presents our econometric framework to measure the impact of the quarantine caused by the 2014 FMD outbreak. Section 4 provides the results. Section 5 concludes.

\section{The 2014 FMD Outbreak and Data Sources 1) The 2014 FMD outbreak}

In Mongolia, the epidemiological unit of an FMD outbreak is in most cases smallholder pastoralist farmers. When an outbreak is declared, the herd that have FMD virus will be stamped out and the government will pay $90 \%$ of the market price as an indemnity payment (Parliament of Mongolia, 2001). After FMD positive herd are compulsory culled, movement control is implemented in the areas surrounding the epidemiological unit, and emergency vaccination is carried out to cloven hoofed livestock in the suspected areas ${ }^{5)}$. Movement control is done in a form of quarantine for a

5) Since FMD is one of the livestock diseases deemed by the Mongolian government as priority, all vaccine costs are covered by the state budget. Cloven hoofed livestock in Mongolia's case are cattle, sheep, goat and camel.

6) Soum (district) is a second level administrative unit after aimag (province).

7) Pastoralists depend on frozen meat products during this time of a year. Livestock birthing season arrives from late February to minimum of 28 days since the outbreak or 14 days since the last vaccination (Ministry of Food and Agriculture, 2014). Quarantine due to FMD outbreak in Mongolia restricts all movement into and out from the area except for authorized persons and delivery of food and other necessary items. Depending on the location of the outbreak, quarantine borders are usually set as the border of a soum or an aimag ${ }^{6}$.

In 2014, there were a total of 15 outbreaks of FMD recorded in 12 unique soums and 1 capital city of an aimag in the south eastern part of Mongolia covering the aimags of Sukhbaatar, Khentii, and Dornogovi bordering to China. The first outbreak was recorded toward the end of January and all the 12 soums and the aimag capital were quarantined from February 14 until April $4^{7)}$. All incoming and outgoing movements were controlled and restricted to only essentials. While the quarantine banned product sales during the quarantine period, after the quarantine was lifted sale and movement of products became free again.

Based on our observations, we postulate the following hypotheses about the impact of quarantine due to the FMD outbreak: (1) it reduced cattle herd size because of infection or culling; (2) it reduced byproduct sales because it was implemented during the period of cashmere and wool sales; (3) it had little impact on livestock sales since quarantine was implemented outside of popular livestock sales season; and (4) it had insignificant impact on total household income since they had other income sources.

\section{2) Data sources}

In this study we use the Household Socio-Economic Survey (HSES) data collected by the National Statistics Office of Mongolia every year. Two-stage stratified random sampling was conducted to select households. At the first stage primary sampling units (PSU's) within each stratum ${ }^{8)}$ were randomly selected with the probability proportional to size. At the second stage, administrative list of households was obtained for each PSU and sample households were randomly chosen. The survey was implemented on a rolling basis, with one twelfth of the sample households interviewed in each month. In this study we pool the 2014 and 2015 HSES to construct a cross-section dataset which covers the

April, and hence farm work becomes hectic. Cashmere and wool shearing activities take place from March until April in eastern provinces, while main meat production season is from October to December.

8) Four strata were considered in the HSES: urban, consisting of aimag capital cities and national capital; and rural, divided into small towns (soum capitals) and countryside substrata. 


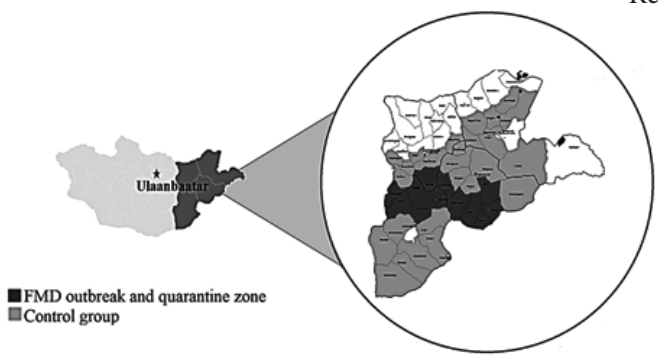

Figure 2. Map of the 2014 FMD quarantine soums and control group soums

years 2013 and 2014 respectively and draw households with livestock and living in rural areas (see footnote 8). Information about FMD outbreak soums is collected from the World Organization for Animal Health World Animal Health Information System (OIE WAHIS) and crosscheck with Mongolian Government orders 2014/39 and 2014/110.

\section{Empirical Strategy}

\section{1) The DID model}

Our basic empirical strategy is a straightforward application of Difference-in-Differences (DID). The DID estimator requires data for at least two time periods and from both treated and un-treated (control) groups. Here, the 'treated group' refers to the cohorts of households residing in soums where an FMD outbreak took place and quarantine regime was imposed in 2014 (hereinafter referred as FMD quarantine). FMD quarantine group consists of 12 contiguous soums as shown in Figure 2, where 358 sample households reside. Since pastoralists' livestock rearing is dependent on climate and grazing ecosystem, we select soums closest to the FMD quarantine group as the control group as shown in Figure $2^{9)}$. The control group covers 28 soums with 723 sample households.

The DID model is given below.

$$
\begin{aligned}
& Y_{\text {ist }}=\beta_{0}+\beta_{1} F M D_{-} \text {Quarantine }_{\text {is }} \mathrm{x} \text { Post }_{i t} \\
& +\beta_{2} \text { Post }_{i t}+\gamma X_{i s t}+\delta E_{s}+\theta M_{i}+\epsilon_{i s t}
\end{aligned}
$$

where $Y_{i s t}$ is the dependent variable of household $i$ in soum $s$ and year $t$. FMD_Quarantine ${ }_{i s}$ is a binary variable taking one if household $i$ in soum $s$ is living in the FMD quarantine zone and Post $_{i t}$ is a binary variable taking one if household $i$ 's observation is after the outbreak of 2014

9) Areas colored white are locations not chosen as control group. The white areas enclosed by control group are aimag capital cities, which are excluded from our analyses.

10) Price of livestock depends on the sex, age, weight of the livestock. Since we lack this information, we use the sales data from farmers in the case of livestock sale and we use the mean
FMD (i.e. from 2015 HSES). The treatment effect is $\beta_{1}$, which measures the relative effect of being in the FMD quarantine zone after 2014 outbreak. $X_{\text {ist }}$ is a vector of household specific characteristics. We use household head age, gender and household size in order to control for innate ability of the household head as well as household's labor supply and food demand. The equation also includes soum fixed effects $E_{s}$ that control for time-invariant characteristics fixed to the soum. $M_{i}$ is a vector of binary variables of the month in which the household $i$ was surveyed to controls if the household $i$ has 2 birthing seasons or 2 slaughtering seasons within the questioning period. The last term in the equation, $\epsilon_{\text {ist }}$, is the error term.

We use clustered standard errors at PSU level because households were randomly selected from the 178 PSUs in the survey, while FMD quarantine regime was implemented at the soum level. Since we have a relatively large number of outcome variables, we adopt multiple hypotheses testing for significant variables, following Benjamini and Hochberg (1995) and Benjamini, Krieger, and Yekutieli (2006), abbreviated as BH1995 and BKY2006, respectively.

\section{2) Descriptive statistics}

Table 1 displays summary and descriptive statistics for households in FMD quarantine soums and control soums across year. Farm product consumption is computed by summing the value of products consumed by the household based on the market price ${ }^{10)}$. Livestock sales value is defined as payment received from selling of livestock in the market. Byproduct sales value is payment received from selling of byproducts such as processed and unprocessed wool and cashmere, skin and hide, and milk. Farm income is defined as the sum of consumption and sales less paid-out cost for feed, fodder, veterinary, hired labor, transportation and others. Then, farm profit is obtained by subtracting imputed costs of family labor ${ }^{11)}$ from the farm income. Paid-out cost of feed and fodder does not include hay from the grasslands which most Mongolian pastoralists prepare by themselves, but it is imputed as part of family labor. Veterinary cost excludes vaccinations, which are covered by the government. To compare monetary variables by unit we use sheep unit (hereinafter mentioned as $\mathrm{SU})^{12}$. Finally, household income

price of the oldest male livestock in the soum in the case of selfconsumption.

11) Family labor costs are computed using the annual minimum wage rate in Mongolia during that year.

12) Sheep unit is calculated by using the following equivalence: cattle $=6$, horse $=7$, camel $=5$, sheep $=1$, goat $=0.9$. 
Table 1. Summary and descriptive statistics

\begin{tabular}{|c|c|c|c|c|c|c|c|c|c|c|}
\hline \multirow[b]{2}{*}{ Variable } & \multirow[b]{2}{*}{ Mean } & \multirow[b]{2}{*}{$\begin{array}{c}\text { Std. } \\
\text { Dev. }\end{array}$} & \multirow[b]{2}{*}{ Min } & \multirow[b]{2}{*}{ Max } & \multicolumn{3}{|c|}{ Control group mean } & \multicolumn{3}{|c|}{ FMD quarantine group mean } \\
\hline & & & & & $\begin{array}{l}\text { Year } \\
2013\end{array}$ & $\begin{array}{l}\text { Year } \\
2014\end{array}$ & Diff. & $\begin{array}{l}\text { Year } \\
2013\end{array}$ & $\begin{array}{l}\text { Year } \\
2014\end{array}$ & Diff. \\
\hline \multicolumn{11}{|c|}{ 1. Household (HH) characteristics } \\
\hline Household size & 3.7 & 1.6 & 1.0 & 10.0 & 3.6 & 3.7 & -0.2 & 3.8 & 3.7 & 0.1 \\
\hline Age of household head & 44.7 & 13.5 & 17.0 & 93.0 & 44.6 & 45.1 & -0.5 & 44.9 & 43.5 & 1.4 \\
\hline Male household head & 0.9 & 0.3 & 0.0 & 1.0 & 0.9 & 0.8 & 0.0 & 0.8 & 0.9 & -0.1 \\
\hline \multicolumn{11}{|l|}{ 2. Herd composition } \\
\hline Herd size (sheep unit) & 600 & 689 & 6.0 & 4790 & 624 & 625 & -1.4 & 598 & 454 & $144^{* *}$ \\
\hline Cattle herd size (number) & 20.3 & 25.8 & 0.0 & 184.0 & 21.5 & 21.4 & 0.1 & 19.9 & 14.0 & $6.0 * *$ \\
\hline \multicolumn{11}{|c|}{ 3. Farm production ( $10^{3} \mathrm{MNT} /$ sheep unit) } \\
\hline Farm product consumption & 12.9 & 13.6 & 0.0 & 210.2 & 11.6 & 13.2 & -1.6 & 14.1 & 15.8 & -1.7 \\
\hline Livestock sales value & 6.8 & 7.9 & 0.0 & 140.5 & 6.5 & 7.7 & -1.2 & 6.3 & 6.9 & -0.6 \\
\hline Byproduct sales value & 4.6 & 4.0 & 0.0 & 35.4 & 4.6 & 4.1 & 0.5 & 5.6 & 3.9 & $1.7 * * *$ \\
\hline Farm income & 22.27 & 15.14 & -15.5 & 216.0 & 20. & 22.5 & -1.8 & 24.1 & 24.6 & -0.5 \\
\hline Farm profit & 13.83 & 19.59 & -192.8 & 216.0 & 11.8 & 13.8 & -2.0 & 16.6 & 16.3 & 0.3 \\
\hline Total farm cost (paid out) & 2.1 & 2.9 & 0.0 & 29.5 & 2.0 & 2.5 & $-0.5 * *$ & 1.9 & 2.0 & -0.1 \\
\hline Feed and fodder cost & 0.7 & 1.4 & 0.0 & 17.7 & 0.6 & 1.0 & $0.4 * * *$ & 0.6 & 0.5 & 0.1 \\
\hline Gasoline, transportation cost & 0.7 & 1.2 & 0.0 & 8.8 & 0.7 & 0.6 & 0.1 & 0.6 & 0.8 & -0.2 \\
\hline Veterinary cost & 0.1 & 0.3 & 0.0 & 4.6 & 0.1 & 0.1 & 0.0 & 0.1 & 0.1 & 0.0 \\
\hline Hired labor cost & 0.3 & 1.0 & 0.0 & 13.1 & 0.3 & 0.3 & 0.0 & 0.4 & 0.1 & 0.2 \\
\hline Imputed family labor cost & 8.4 & 16.1 & 0.0 & 232.7 & 8.8 & 8.7 & 0.2 & 7.5 & 8.3 & -0.8 \\
\hline \multicolumn{11}{|c|}{ 4. Household welfare ( $10^{3} \mathrm{MNT} /$ capita) } \\
\hline Household income & 3460 & 3189 & 29 & 29032 & 3338 & 3474 & -136 & 3510 & 3853 & -343 \\
\hline Number of Observations & \multicolumn{4}{|c|}{1081} & 489 & 234 & & 244 & 114 & \\
\hline
\end{tabular}

Note: ${ }^{* *} \mathrm{p}<0.01$ and ${ }^{* *} \mathrm{p}<0.05$ indicate year 2013 and year 2014 means are significantly different from zero based on t-test.

Farm products include livestock and its byproducts such as cashmere, wool, skin and hide, milk etc.

MNT stands for Mongolian currency, Tugrug. In 2014, 1,000 MNT was equivalent to 0.53 USD.

is calculated as the sum of flows received including farm revenue, crop revenue, business revenue, salary income, and other income such as sales/rental of non-livestock assets, withdrawal of bank savings, state benefit like pension, aid from government, private gifts, etc.

\section{3) SUTVA condition}

In order for the DID model to identify the causal impact of the FMD quarantine effectively, Stable Unit Treatment Value Assumption (SUTVA) must be satisfied (Rubin, 1990). In our context, there are two potential cases of violation of SUTVA. One is household movement between treatment soums and control soums (i.e. contaminations). The other is spillover of quarantine effect to control soums. We strongly believe that SUTVA condition is largely satisfied in our data for the following reasons.

For the first case, although we do not have the data about household relocation, since relocation beyond a soum is not so frequent, it is safe to assume that contamination is very few within the two-year period of two HSES's. It is partially confirmed in Table 1, which shows average household characteristics do not change before and after the quarantine in both treatment and control groups.

As for the second case, spillover can happen if market is shared by treatment and control groups and if the market prices are affected by the quarantine. In our study site, households usually sell livestock and animal byproducts and buy some kinds of feeds (feeds with additives and fermented feeds) in the market in the capital city of the aimag, to which both treatment soums and controls soums belong. Therefore, the two groups share the market. However, we can confirm that price trend in the three quarantined aimags is similar to that in non-quarantined aimags in the case of livestock, byproducts, and gasoline (data are not shown in this paper). Although price data about feeds additives and fermented feeds are not available, there is no strong reason that their prices move differently from other products. Therefore, the prices in the shared market are not affected by the quarantine. In addition, since fodder and hired labor markets are in most cases within a soum, there should be little spillover across soums. Thus, overall spillover can be considered negligible. 
Table 2. FMD quarantine impact on farming performance

\begin{tabular}{|c|c|c|c|c|c|c|c|c|c|c|c|}
\hline $\begin{array}{c}\text { Dependent } \\
\text { variable }\end{array}$ & $\begin{array}{c}\text { Total } \\
\text { herd size }\end{array}$ & $\begin{array}{l}\text { Cattle herd } \\
\text { size }\end{array}$ & $\begin{array}{c}\text { Farm } \\
\text { product } \\
\text { consump- } \\
\text { tion }\end{array}$ & $\begin{array}{c}\text { Livestock } \\
\text { sales }\end{array}$ & $\begin{array}{l}\text { By- } \\
\text { product } \\
\text { sales }\end{array}$ & $\begin{array}{l}\text { Farm } \\
\text { income }\end{array}$ & $\begin{array}{l}\text { Farm } \\
\text { profit }\end{array}$ & $\begin{array}{c}\text { Total farm } \\
\text { costs } \\
\text { (paid out) }\end{array}$ & $\begin{array}{c}\text { Feed and } \\
\text { fodder } \\
\text { cost }\end{array}$ & $\begin{array}{l}\text { Gasoline, } \\
\text { transportat } \\
\text { ion cost }\end{array}$ & $\begin{array}{c}\text { Veteri- } \\
\text { nary } \\
\text { cost }\end{array}$ \\
\hline $\begin{array}{c}\text { FMD_Quaranti } \\
\text { ne x Post }\end{array}$ & $\begin{array}{c}-178.9^{* *} \\
(85.6)\end{array}$ & $\begin{array}{c}-7.39 * * \\
(3.03)\end{array}$ & $\begin{array}{l}-0.28 \\
(2.13)\end{array}$ & $\begin{array}{l}-1.16 \\
(1.19)\end{array}$ & $\begin{array}{c}-1.41^{* *} \\
(0.58)\end{array}$ & $\begin{array}{l}-2.27 \\
(2.52)\end{array}$ & $\begin{array}{l}-1.04 \\
(3.64)\end{array}$ & $\begin{array}{l}-0.57 \\
(0.45)\end{array}$ & $\begin{array}{c}-0.63 * * * \\
(0.2)\end{array}$ & $\begin{array}{c}0.23 \\
(0.19)\end{array}$ & $\begin{array}{l}-0.02 \\
(0.04)\end{array}$ \\
\hline $\begin{array}{c}\text { Unadjusted } \\
\text { p-value }\end{array}$ & 0.04 & 0.02 & 0.89 & 0.33 & 0.02 & 0.36 & 0.77 & 0.21 & 0.00 & 0.24 & 0.56 \\
\hline $\begin{array}{c}\text { BKY 2006 } \\
\text { p-value }\end{array}$ & 0.03 & 0.03 & 0.88 & 0.96 & 0.09 & 0.96 & 0.88 & 0.62 & 0.02 & 0.62 & 0.88 \\
\hline $\begin{array}{c}\text { BH } 1995^{\text {a) }} \\
\text { p-value }\end{array}$ & 0.04 & 0.03 & 0.89 & 0.61 & 0.09 & 0.61 & 0.89 & 0.47 & 0.02 & 0.47 & 0.73 \\
\hline
\end{tabular}

Note: ${ }^{* *} \mathrm{p}<0.01,{ }^{* *} \mathrm{p}<0.05$. Robust standard errors clustered at primary sampling unit are in parentheses. Sample size is 1081 . The unit of each dependent variable is the same as shown in Table 1. We control for household characteristics shown in Table 1 as well as total herd size in sheep unit at the beginning of survey year (in the case of monetary dependent variables), soum fixed effects, and month fixed effects. a) BKY 2006 and BH 1995 are adjusted $p$-values calculated based on Benjamini et al. (2006) and Benjamini and Hochberg (1995) respectively.

\section{Results}

\section{1) Herd composition}

Herd composition regression results are shown in Table 2. It shows that herders living in a soum that had an FMD outbreak and later quarantined decreased total herd size by 178.9 sheep units and cattle herd by 7.39 heads, significantly at $5 \%$ level. In reference to the mean of herd sizes shown in Table 1, the coefficients of the regression are considerably large. It could be because some cattle were killed due to FMD infection and others were culled to prevent epidemic. In addition, in quarantine zones some households slaughtered frail cattle selectively to avoid infection and self-consumed it.

\section{2) Farm revenue, income, profit and cost}

Significant impact of the FMD quarantine is observed only byproduct sales and feed/fodder cost as shown in Table 2. Since the quarantine was placed in the eastern province during the main season of wool and cashmere, the decrease in byproduct sales should be due to the loss of opportunity in cashmere and wool sales ${ }^{13)}$. But the quarantine did not influence on livestock sales because the quarantine was well before the main meat market season. Feed/fodder cost decreased naturally because herd size became smaller, but also because households in the quarantine soums stopped purchasing feed during the quarantine period. However, since other cost like hired labor did not change, total paid-out cost did not decrease significantly. As a result, there is no significant impact of quarantine on farm income, and on farm profit either since family labor cost was not affected.

13) For cashmere and wool, the timing of sale is quite important since it is directly related to the quality of the product. Wool and cashmere sheared/prepared after the optimal date would result in product with more dust.

\section{3) Household income}

Our estimation result of per capita income regression shows no evidence of negative impact of FMD quarantine as shown in Table 3. Although we do see a significant decrease in byproduct sales, total household income does not show significant change. Rather, the impact is even positive although it is not statistically significant. Each household has diverse income sources other than farming as already mentioned, among which major ones are salary, business, public and private transfer, and non-livestock assets. Applying the same DID model to major non-farming income sources, we find private transfer including NGO's aid increased significantly due to the quarantine and hence contributed to the mitigation of negative shock due to the quarantine ${ }^{14)}$ (the results are not shown in this paper).

It should be noted that we do not know which households in our sample had an FMD infection and received indemnity payment and we do not know how much it was either.

Table 3. FMD quarantine impact on household welfare

\begin{tabular}{cc}
\hline Dependent variable & Total income \\
\hline \hline FMD_Quarantine x Post & 619.89 \\
& $(450.21)$ \\
\hline
\end{tabular}

Note: Please refer to Table 2. Unadjusted p-value is 0.17 . Adjusted p-values of BKY 2006 and BH 1995 are 0.58 and 0.44 .

\section{4) Robustness check}

As a robustness check, we implement the same regressions using HSES 2013 and 2014 when there was no FMD quarantine. We find no significant results, suggesting that in

14) Sales/rental of non-livestock assets including withdrawal of bank savings also increased, but not significantly after adjusted for multiple hypothesis testing. 
the absence of FMD quarantine, the difference between the 'treatment' and 'control' groups is constant over time (i.e. parallel trend). Parallel trend of the outcome variables is also confirmed graphically from 2011 to 2014 . The results are not given in this paper, but available from the authors.

\section{Conclusion}

We analyze the impact of prolonged quarantine caused by the 2014 FMD outbreak in Mongolia on pastoralists' farming performance (e.g. herd composition, farm product consumption, sales, income, profit, costs) and their household welfare. Using the quarantine zoning restricting all movement (human and livestock) across the zone as a treatment, we implement DID regressions on a pooled crosssectional dataset constructed from two rounds of HSES.

Our results show that households living in the FMD quarantine soums decreased total herd size and the number of cattle after the event. Given that not all households in the treatment group had FMD positive livestock in our sample, the decrease happened probably because households tried to avoid the risk of FMD outbreak in their own herd by culling weak cattle selectively in the herd.

Byproduct sales revenue significantly decreased due to the quarantine, but livestock sales revenue was not affected. This result indicates that the prolonged quarantine restricted the sales of some products, especially wool and cashmere.

Nevertheless, we do not observe any significant change due to the quarantine in overall household welfare assessed by total household income per capita. Given the significant and big decrease in total herd size and the number of cattle, however, the impact may become observable 3 to 4 years later. Moreover, an asset-based welfare assessment may capture even immediate negative impacts of the quarantine. Thus, long-term as well as asset-based impacts of FMD quarantine should be investigated in the future.

As for policy implications from our findings: first, government should improve the measures to relieve households of quarantine burden such as allowing sanitized wool and cashmere products to sell, and delivering feed and fodder during quarantine period; and second, it will be necessary to develop a way to support households to recover herd size quickly to avoid any long-term negative impact.

\section{References}

Benjamini, Y. and Y. Hochberg (1995) Controlling the False Discovery Rate: A Practical and Powerful Approach to Multiple
Testing, Journal of the Royal Statistical Society: Series B (Methodological) 57(1): 289-300.

Benjamini, Y., A. M. Krieger, and D. Yekutieli (2006) Adaptive Linear Step-up Procedures That Control the False Discovery Rate, Biometrika 93(3): 491-507.

Knight-Jones, T. J. D., M. McLaws, and J. Rushton (2017) Footand-Mouth Disease Impact on Smallholders - What Do We Know, What Don't We Know and How Can We Find Out More? Transboundary and Emerging Diseases 64(4):1079-1094.

Cervigni, R. and M. Morris (2016) Confronting Drought in Africa's Drylands: Opportunities for Enhancing Resilience, Washington, DC: World Bank.

FAO (2009) The State of Food and Agriculture 2009: Livestock in the Balance, Rome: Food and Agriculture Organization.

Minister of Food and Agriculture (2008) Procedure of Foot-andMouth Disease Prevention, Control in Livestock and Animals. Order No. A/93.

National Statistics Office of Mongolia (2019) Agriculture Sector 2018, Ulaanbaatar: National Statistics Office of Mongolia.

Parliament of Mongolia (2001) Law on Protection of Livestock Genetics, Health, Ulaanbaatar: Parliament of Mongolia. (repealed with reenactment in 2017)

Parliament of Mongolia (2015) State Policy on Food and Agriculture, Ulaanbaatar: Parliament of Mongolia.

Parliament of Mongolia (2020) Concept of 'Law of Animal, Livestock' Floored to the Parliament in 2016. Retrieved from Parliament of Mongolia website: http://forum.parliament.mn /files/12722/.

Rae, A. and R. Nayga (2013) Trends in Consumption, Production, and Trade in Livestock and Livestock Products, in H. Steinfeld, H. A. Mooney, F. Schneider, and L. E. Neville, eds., Livestock in a Changing Landscape, Volume 1: Drivers, Consequences, and Responses, Island Press, 11-34.

Rubin, D. B. (1990) Fromal Modes of Statistical Inference for Causal Effects, Journal of Statistical Planning and Inference 25: 279-292.

Rich, K. M. and A. Winter-Nelson (2007) An Integrated Epidemiological-economic Analysis of Foot and Mouth Disease: Applications to the Southern Cone of South America, American Journal of Agricultural Economics 89(3): 682-697.

Purevkhuu, T. (2016) Untitled Report, Mongolian Veterinary Medicine, 6/125: 16.

Wang, T. and D. A. Hennessy (2015) Strategic Interactions among Private and Public Efforts when Preventing and Stamping Out a Highly Infectious Animal Disease, American Journal of Agricultural Economics 97(2): 435-451.

World Organisation for Animal Health (2019) Retrieved from https:/www.oie.int/en/animal-health-in-the-world/animaldiseases/Foot-and-mouth-disease/. 